\title{
TEMPERATURE DURING SOYBEAN SEED STORAGE AND THE AMOUNT OF ELECTROLYTES OF SOAKED SEEDS SOLUTION
}

\author{
Roberval Daiton Vieira ${ }^{1 *}$; Dennis Merlin TeKrony²; Dennis Bruce Egli²; William Patrick \\ Bruenning $^{2}$; Maristela Panobianco ${ }^{3}$ \\ ${ }^{1}$ UNESP/FCAV - Depto. de Produção Vegetal, Via de Acesso Prof. Paulo Donato Castellane, s/n - 14884-900 - \\ Jaboticabal, SP - Brasil. \\ ${ }^{2}$ University of Kentucky - Department of Agronomy, 40546-0091, Lexington, KY - USA. \\ ${ }^{3}$ UFPR/SCA - Depto. de Fitotecnia e Fitossanitarismo, R. dos Funcionários, 1540 -80035-050 - Curitiba, PR - \\ Brasil. \\ *Corresponding author 〈rdvieira@fcav.unesp.br>
}

\begin{abstract}
The electrical conductivity test measures the electrolytes that leach out of seeds when they are immersed in water and this leakage is an indication of seed vigor. The level of standardization reached by the procedures of this test is such that the test is recommended for pea seeds and suggested for other large seeded legumes, including soybean [Glycine max (L.) Merrill]. This study was conducted to contribute to the standardization of this test for soybean seeds by verifying whether the seed storage temperature influences the composition of the leachate from soaked seeds solution. Two soybean seed lots of distinct physiological potential were stored in moisture-proof containers either at constant temperatures of $10^{\circ} \mathrm{C}$ and $20^{\circ} \mathrm{C}$ or at the temperature of $20^{\circ} \mathrm{C}$ during the first seven months of storage followed by a change to $10^{\circ} \mathrm{C}$ for the rest of the storage time (nine months). The chemical composition of the soaked water was evaluated every three months from January to October 1998. The highest amount of leakage was observed for potassium, followed by calcium and magnesium, iron and sodium regardless of temperature and storage period. The amount of electrolytes in the soaked water increased as the period of time and the temperature of storage increased. On the other hand the amount of leakage decrease along the time for those seeds stored at $10^{\circ} \mathrm{C}$ or transferred from the temperature of 20 to that of $10^{\circ} \mathrm{C}$. The temperature at which soybean seeds remain during storage may affect the amount of electrolytes in the soaked water and consequently the results of the electrical conductivity test.
\end{abstract}

Key words: Glycine max, vigor, deterioration

\section{TEMPERATURA DE ARMAZENAMENTOE QUANTIDADE DE LIXIVIADOS NA SOLUÇÃO DE EMBEBIÇÃO DE SEMENTES DE SOJA}

RESUMO: O teste de condutividade elétrica mede a quantidade de eletrólitos liberada das sementes quando imersas em água, sendo um indicador do vigor da semente. O teste é recomendado para sementes de ervilha e sugerido para outras leguminosas, incluindo a soja [Glycine max (L.) Merrill]. O presente trabalho visa contribuir para a padronização do referido teste para avaliação do vigor de sementes de soja, procurando verificar se a temperatura de armazenamento da semente pode influenciar a liberação de eletrólitos na solução de embebição das sementes. Dois lotes de sementes de soja de potenciais fisiológicos distintos foram acondicionados em embalagens herméticas e armazenados em três ambientes: 10 e $20^{\circ} \mathrm{C}$ (constantes) e $20^{\circ} \mathrm{C}$ por sete meses, com transferência para $10^{\circ} \mathrm{C}$ até o final do armazenamento (mais nove meses). A composição química da solução de embebição das sementes foi analisada a cada período de três meses, de janeiro a outubro de 1998. Os maiores valores de lixiviação foram observados para potássio, seguido de cálcio e magnésio, ferro e sódio. Verificou-se acréscimo na quantidade de eletrólitos na solução de embebição em função do aumento do período e da temperatura de armazenamento. Por outro lado, observou-se decréscimo na quantidade de lixiviados ao longo do tempo para as sementes armazenadas a $10^{\circ} \mathrm{C}$ ou transferidas da temperatura de $20^{\circ} \mathrm{C}$ para $10^{\circ} \mathrm{C}$. A temperatura de armazenamento de sementes de soja pode interferir na liberação de eletrólitos na solução de embebição e, conseqüentemente, nos resultados do teste de condutividade elétrica.

Palavras-chave: Glycine max, vigor, deterioração 


\section{INTRODUCTION}

Cell membranes attain their maximum level of organization at seed physiological maturity (Abdul-Baki, 1980). After that point, seed dehydration causes a structural disorganization of cell membranes, and this disorganization is greatest when seeds reach water content levels low enough to allow mechanical harvesting (Bewley \& Black, 1994). On the other hand, the integrity of cell membranes, as determined by the degree of biochemical changes and/or physical damage, may be considered the fundamental cause of differences in seed vigor (Powell, 1988).

The electrical conductivity (EC) test was proposed to evaluate the vigor level of pea (Pisum sativum L.) seeds due to the fact that the lower the seed vigor, the lesser is its capacity to restore cell membrane integrity which results in increased amounts of electrolytes leached to the soaked water during seed imbibition. This leachate has been reported by several investigators to contain sugars, amino acids, fatty acids, enzymes, and inorganic ions, such as $\mathrm{K}^{+}, \mathrm{Ca}^{++}, \mathrm{Mg}^{++}$, and $\mathrm{Na}^{+}$(AOSA, 2002; Loomis \& Smith, 1980; Givelberg et al., 1984; Woodstock, 1988; Cortes \& Spaeth, 1994; Lott et al., 1991; Taylor et al., 1995).

In the EC test, seed quality is indirectly evaluated through the determination of the $\mathrm{EC}$ of the solution resulting from the soaking of seeds in water. The amount of electrolytes leached from high vigor seeds is low leading to low conductivities. Low conductivities are considered to be an indication of high vigor because it is thought to represent a low level of cell membrane system disorganization. Some papers have reported significant relationships between the results of the EC test and seedling emergence in the field (Vieira et al., 1999ab, 2004).

Some of this research considered the possibility that the temperatures during seed storage influence the EC test. Ferguson (1988) and Vieira et al. (2001) reported that, after being stored under low temperatures for some period, soybean seeds that showed a significant drop in germination and vigor (accelerated aging) did not show an equivalent drop in physiological quality evaluated by means of the EC.

Thus, having in mind the close relation between the EC test results and the leaching of electrolytes during the imbibition of seeds in water, the objective of this research was to study the chemical composition of the soak water of soybean seeds stored at different temperatures.

\section{MATERIAL AND METHODS}

This study was conducted in Lexington, KY, USA between September of 1997 and October of 1998. Two soybean [Glycine max (L.) Merrill] seed lots with distinctly different physiological quality were used (Table 1) and also described previously by Vieira et al. (2001).

The seeds were packed in moisture proof containers and stored for 16 months at the following temperatures: (i) constant $10^{\circ} \mathrm{C}$, (ii) constant $20^{\circ} \mathrm{C}$, and (iii) at the temperature of $20^{\circ} \mathrm{C}$ during the first seven months which was followed by an additional nine

Table 1 - Seed water content (WC -fresh weight basis) and initial and final seed quality - standard germination (SG), accelerated aging (AA) and electrical conductivity (EC) of soybean seed lots.

\begin{tabular}{|c|c|c|c|c|}
\hline Storage temp. & WC & SG & AA & EC \\
\hline & \multicolumn{4}{|c|}{ June/1997 } \\
\hline \multirow[t]{2}{*}{${ }^{\circ} \mathrm{C}$} & - - & $-\cdots$ & 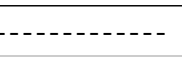 & 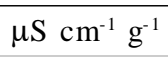 \\
\hline & \multicolumn{4}{|c|}{ Lot $1-$ high vigor } \\
\hline \multirow[t]{2}{*}{-} & 12.3 & 99 & 95 & 58 \\
\hline & \multicolumn{4}{|c|}{ Lot 2 - low vigor } \\
\hline \multirow[t]{3}{*}{-} & 11.9 & 94 & 65 & 73 \\
\hline & \multicolumn{4}{|c|}{ October/1998 } \\
\hline & \multicolumn{4}{|c|}{ Lot 1 - high vigor } \\
\hline 10 & 12.2 & 95 & 82 & 64 \\
\hline 20 & 12.2 & 30 & 0 & 126 \\
\hline \multirow[t]{2}{*}{$20 / 10$} & 12.2 & 94 & 35 & 68 \\
\hline & \multicolumn{4}{|c|}{ Lot 2 - low vigor } \\
\hline 10 & 12.1 & 82 & 4 & 80 \\
\hline 20 & 12.0 & 4 & 0 & 172 \\
\hline $20 / 10$ & 12.1 & 79 & 0 & 92 \\
\hline
\end{tabular}


months at $10^{\circ} \mathrm{C}$. At three months interval, from January to October 1998, the seeds were sampled and tested for the electrical conductivity (Vieira et al., 2001) until the end of the storage period and at each sampling the chemical composition of the soak water was determined. The procedure for electrical conductivity consisted of imbibing four replicates of 50 seeds in $75 \mathrm{~mL}$ of deionised water for 24 hours at a constant temperature of $25^{\circ} \mathrm{C}$ and the bulk electrical conductivity was measured using a conductivity meter as described by Hampton \& TeKrony (1995) and Vieira \& Krzyzanowski (1999). After that, the soak water was filtered and the following chemical elements measured: $\mathrm{K}$ and $\mathrm{Na}$ by means of the flame photometry process, $\mathrm{Ca}, \mathrm{Mg}$ and $\mathrm{Fe}$ by the atomic absorption spectrophotometry method (Bataglia et al., 1983; Tomé Júnior, 1997).

The experimental units were arranged in a completely random design with a split-plot arrangement of treatments in four replicates. The main plots were storage temperatures $\left(10,20\right.$, and $\left.20 / 10^{\circ} \mathrm{C}\right)$ and the split-plots were sampling times $(7,10,13$ and 16 months of storage). The two seed lots were analyzed separately. The comparison between means was accomplished by the Tukey test $(p<0.05)$.

\section{RESULTS AND DISCUSSION}

When stored at $10^{\circ} \mathrm{C}$ the seeds of both vigor levels showed no difference as to $\mathrm{K}^{+}$content in the soak water at any time during the storage period (Table 2). But, when the temperature was of $20^{\circ} \mathrm{C}$, the amount of potassium leached after13 and 16 months of storage readings was higher than those after seven and 10 months. This pattern of response was confirmed by the third storage condition (seven months at 20 followed by nine months at $10^{\circ} \mathrm{C}$ ) that is, storing soybean seeds at low temperatures causes a reduction in the leached potassium. These patterns were observed independently of the seed vigor level. Also the electrical conductivity results followed a similar patterns as potassium was leached (Table 3). The reduction of

Table 2 - Potassium content in the soak water of soybean seeds stored for several periods of time.

\begin{tabular}{lrrr}
\hline \multirow{2}{*}{ Evaluation } & \multicolumn{3}{c}{ Storage temperature } \\
\cline { 2 - 4 } & $10^{\circ} \mathrm{C}$ & $20^{\circ} \mathrm{C}$ & $20 / 10^{\circ} \mathrm{C}$ \\
\hline months & & Potassium content $\left(\mathrm{mg} \mathrm{L}^{-1}\right)$ (Lot 1 - high vigor) \\
\hline 7 & $952 \mathrm{aA}$ & $1054 \mathrm{bA}$ & $1044 \mathrm{aA}$ \\
10 & $832 \mathrm{aA}$ & $1049 \mathrm{bA}$ & $871 \mathrm{aA}$ \\
13 & $737 \mathrm{aC}$ & $2001 \mathrm{aA}$ & $1445 \mathrm{aB}$ \\
16 & $646 \mathrm{aB}$ & $2106 \mathrm{aA}$ & $866 \mathrm{aB}$ \\
\hline 7 & & Potassium content $\left(\mathrm{mg} \mathrm{L}^{-1}\right)($ Lot $2-$ low vigor) & $1305 \mathrm{aA}$ \\
10 & $1239 \mathrm{aA}$ & $1530 \mathrm{aA}$ & $987 \mathrm{aA}$ \\
13 & $930 \mathrm{aA}$ & $1487 \mathrm{bA}$ & $1575 \mathrm{aAB}$ \\
16 & $1022 \mathrm{aB}$ & $2223 \mathrm{abA}$ & $976 \mathrm{aB}$ \\
\hline
\end{tabular}

Means followed by the same small case letter in the column and large case letter in the line do not differ (Tukey's test, $p<0.05$ ).

Table 3 - Electrical conductivity of soybean seeds stored for several periods of time.

\begin{tabular}{|c|c|c|c|}
\hline \multirow{2}{*}{ Evaluation moment } & \multicolumn{3}{|c|}{ Storage temperature } \\
\hline & $10^{\circ} \mathrm{C}$ & $20^{\circ} \mathrm{C}$ & $20 / 10^{\circ} \mathrm{C}$ \\
\hline months & \multicolumn{3}{|c|}{ Electrical conductivity $\left(\mu \mathrm{S} \mathrm{cm}^{-1} \mathrm{~g}^{-1}\right)($ Lot $1-$ high vigor $)$} \\
\hline 7 & $68 \mathrm{aB}$ & $77 \mathrm{bA}$ & $71 \mathrm{aAB}$ \\
\hline 10 & $63 \mathrm{aB}$ & $76 \mathrm{bA}$ & $63 \mathrm{abB}$ \\
\hline 13 & $58 \mathrm{aB}$ & $84 \mathrm{bA}$ & $60 \mathrm{bB}$ \\
\hline \multirow[t]{2}{*}{16} & $64 \mathrm{aB}$ & $126 \mathrm{aA}$ & $68 \mathrm{abB}$ \\
\hline & \multicolumn{3}{|c|}{ Electrical conductivity $\left(\mu \mathrm{S} \mathrm{cm}^{-1} \mathrm{~g}^{-1}\right)($ Lot $2-$ low vigor $)$} \\
\hline 7 & $83 \mathrm{aB}$ & $101 \mathrm{bA}$ & $90 \mathrm{bAB}$ \\
\hline 10 & $75 \mathrm{aB}$ & $112 \mathrm{bA}$ & $83 \mathrm{bB}$ \\
\hline 13 & $72 \mathrm{aB}$ & $116 \mathrm{bA}$ & $73 \mathrm{bB}$ \\
\hline 16 & $80 \mathrm{aB}$ & $172 \mathrm{aA}$ & $92 \mathrm{aB}$ \\
\hline
\end{tabular}

Means followed by the same small case letter in the column and large case letter in the line do not differ (Tukey's test, $p<0.05$ ). 
electrical conductivity of soaked seed stored at low temperature $\left(10^{\circ} \mathrm{C}\right)$ compared to higher temperatures $\left(20^{\circ} \mathrm{C}\right)$ confirm those reported by Ferguson (1988) and Vieira et al. (2001) both working with soybean seeds, however it was not clear for corn seeds (Fessel et al., 2006).

Similar responses were also observed with $\mathrm{Ca}$ (Table 4), Mg (Table 5) and Fe (Table 6). The only element without alteration for both seed vigor levels was sodium (Table 7).

Potassium was the most abundant ion in the soak water, this being a confirmation of data published by Loomis \& Smith (1980) working with cabbage seeds (Brasssica Oleracea L. capitata), Lott et al. (1991) working with peanut (Arachis hypogaea L.), pea (Pisum sativum L.) and soybean [Glycine $\max (\mathrm{L}$.) Merrill] and Fessel (2001) working with corn and soybean seeds. Lott et al. (1991) and Fessel (2001) verified that as storage time increased the amount of potassium lost into the imbibing solution also increased.
That is one of the reasons why the determination of the amount of $\mathrm{K}$ in the soak water has been proposed as a vigor test for soybean (Dias et al., 1997) and peanut (Vanzolini \& Nakagawa, 2003) seeds.

It seems that the electrical conductivity variation results is closely related to the amount of the potassium, calcium and magnesium ions into the soaked water of seeds. This was also reported by Fessel (2001) for soybean seeds, who found that when the electrical conductivity values increase the results of potassium, calcium and magnesium also increase in the imbibition solution. The temperature played an important role on soybean seed vigor after stored under low temperatures, such as cold room temperature $\left(10^{\circ} \mathrm{C}\right)$.

Why low temperature such as $10^{\circ} \mathrm{C}$ lead to a reduction on electrical conductivity and also potassium, calcium and magnesium leached from the soaked seeds? Other authors tried to explain this subject. For instance, Vieira et al. (2001) working with soybean seeds mentioned that membranes also stabilized for

Table 4 - Calcium content in the soak water of soybean seeds stored for several periods of time.

\begin{tabular}{lccc}
\hline \multirow{2}{*}{ Evaluation } & \multicolumn{3}{c}{ Storage temperature } \\
\cline { 2 - 4 } months & $10^{\circ} \mathrm{C}$ & $20^{\circ} \mathrm{C}$ & $20 / 10^{\circ} \mathrm{C}$ \\
\hline 7 & & Calcium content $\left(\mathrm{mg} \mathrm{L}^{-1}\right)$ (Lot 1 - hight vigor) \\
10 & $42 \mathrm{aA}$ & $56 \mathrm{bA}$ & $45 \mathrm{abA}$ \\
13 & $27 \mathrm{abB}$ & $51 \mathrm{bA}$ & $30 \mathrm{bB}$ \\
16 & $37 \mathrm{abB}$ & $95 \mathrm{aA}$ & $56 \mathrm{aB}$ \\
\hline & $19 \mathrm{bB}$ & $83 \mathrm{aA}$ & $32 \mathrm{bB}$ \\
10 & & Calcium content $\left(\mathrm{mg} \mathrm{L}^{-1}\right)($ Lot $2-$ low vigor) & $68 \mathrm{abA}$ \\
13 & $55 \mathrm{aA}$ & $66 \mathrm{bA}$ & $53 \mathrm{abA}$ \\
16 & $51 \mathrm{aA}$ & $60 \mathrm{bA}$ & $80 \mathrm{aB}$ \\
\hline
\end{tabular}

Means followed by the same small case letter in the column and large case letter in the line do not differ (Tukey's test, $p<0.05$ ).

Table 5 - Magnesium content in the soak water of soybean seeds stored for several periods of time.

\begin{tabular}{lccc}
\hline \multirow{2}{*}{ Evaluation } & \multicolumn{3}{c}{ Storage temperature } \\
\cline { 2 - 4 } & $10^{\circ} \mathrm{C}$ & $20^{\circ} \mathrm{C}$ & $20 / 10^{\circ} \mathrm{C}$ \\
\hline months & & Magnesium content $\left(\mathrm{mg} \mathrm{L}^{-1}\right)$ (Lot 2 -high vigor) \\
\hline 7 & $35 \mathrm{aA}$ & $51 \mathrm{bA}$ & $45 \mathrm{abA}$ \\
10 & $35 \mathrm{aA}$ & $62 \mathrm{bA}$ & $42 \mathrm{abA}$ \\
13 & $44 \mathrm{aB}$ & $111 \mathrm{aA}$ & $53 \mathrm{aB}$ \\
16 & $21 \mathrm{aB}$ & $127 \mathrm{aA}$ & $24 \mathrm{bB}$ \\
\hline 7 & & Magnesium content (mg L-1) (Lot 2- low vigor) & $48 \mathrm{aA}$ \\
10 & $38 \mathrm{aA}$ & $56 \mathrm{cA}$ & $43 \mathrm{aA}$ \\
13 & $44 \mathrm{aA}$ & $73 \mathrm{bcA}$ & $69 \mathrm{aAB}$ \\
16 & $48 \mathrm{aB}$ & $113 \mathrm{abA}$ & $34 \mathrm{aB}$ \\
\hline
\end{tabular}

Means followed by the same small case letter in the column and large case letter in the line do not differ (Tukey's test, $p<0.05$ ). 
Table 6 - Iron content in the soak water of soybean seeds stored for several periods of time.

\begin{tabular}{lcc}
\hline \multirow{2}{*}{ Storage temperature } & \multicolumn{2}{c}{ Iron content } \\
\cline { 2 - 3 } & Lot 1 (high vigor) & Lot 2 (low vigor) \\
\hline${ }^{\circ} \mathrm{C}$ & $12.35 \mathrm{a}$ & $11.13 \mathrm{~b}$ \\
10 & $12.80 \mathrm{a}$ & $13.35 \mathrm{a}$ \\
20 & $11.93 \mathrm{a}$ & $13.33 \mathrm{a}$ \\
\hline
\end{tabular}

Means followed by the same small case letter in the column do not differ (Tukey's test, $p<0.05$ ).

Table 7 - Sodium content in the soak water of soybean seeds stored for several periods of time.

\begin{tabular}{lcc}
\hline \multirow{2}{*}{ Storage temperature } & \multicolumn{2}{c}{ Iron content } \\
\cline { 2 - 3 } & Lot 1 (high vigor) & Lot 2 (low vigor) \\
\hline${ }^{\circ} \mathrm{C}$ & $2.16 \mathrm{a}$ & $2.34 \mathrm{a}$ \\
10 & $1.83 \mathrm{a}$ & $2.23 \mathrm{a}$ \\
20 & $1.84 \mathrm{a}$ & $1.85 \mathrm{a}$ \\
\hline
\end{tabular}

Means followed by the same small case letter in the column do not differ (Tukey's test, $p<0.05$ ).

seeds stored at $10^{\circ} \mathrm{C}$, resulting in no increase in conductivity as a result of no increase in the ions leached. This can raise some questions. Why should seeds stored at $10^{\circ} \mathrm{C}$ apparently stabilize membranes more than seeds stored at $30^{\circ} \mathrm{C}$, for instance, resulting in lower value of EC? Some hypothesis can be raised. First, the transition from a period of relative membrane stability to dynamic seed aging could occur through a loss of the glassy state (Bernal-Lugo \& Leopold, 1998). This loss could be influenced by an increase in the water content, in temperature, or by a separation of sugars involved. Besides that, the beginning of deterioration could result from a gradual hydrolysis of the soluble sugars. The hydrolysis of sugars presented in seeds would lead to an accumulation of reducing sugars that would finally threaten the proteins integrity as a result of the formation of Maillard products (Sun \& Leopold, 1995). However, it can only be speculated that one or more of the above factors may be involved in the lack of response in EC when seeds were stored at $10^{\circ} \mathrm{C}$.

It also can be stated some relationship with seed water content. However it was monitored during the whole period of the experiment and there is no variation on it. The initial and final values of water content were shown on Table 1. It remained close to $12 \%$ during the whole storage period (16 months).

Considering these results and others (Ferguson, 1988 and Vieira et al., 2001) the vigor evaluation of soybean seeds using the electrical conductivity test raise some concerns when the seeds are stored at low temperatures such as $10^{\circ} \mathrm{C}$. However, in general soybean seeds are stored under this condition very rarely, unless genetic seeds. In this case this situation must be consider. Also some research need to be done studying the period of time after the seeds are removed from $10^{\circ} \mathrm{C}$ to be evaluated through electrical conductivity test.

\section{CONCLUSION}

The temperature at which soybean seeds remain while in storage affects the amount of electrolytes leached during the electrical conductivity test thus having a potential to mask results.

\section{ACKNOWLEDGMENTS}

To FAPESP and to CNPq for the granted scholarships.

\section{REFERENCES}

ABDUL-BAKI, A.A. Biochemical aspects of seed vigour. HortScience, v.15, p.765-771, 1980.

ASSOCIATION OF OFFICIAL SEED ANALYSTS - AOSA. Seed vigor testing handbook. East Lasing: AOSA, 2002. 103p. (Contribution, 32)

BATAGLIA, O.C.; FURLANI, A.M.C.; TEIXEIRA, J.P.F.; FURLANI, P.R.; GALLO, J.R. Métodos de análise química de plantas. Campinas: Instituto Agronômico, 1983. 48p. (Boletim Técnico, 78).

BERNAL-LUGO, I.; LEOPOLD, A.C. The dynamics of seed mortality. Journal of Experimental Botany, v.49, p.14551461,1998

BEWLEY, J.D.; BLACK, M. Seeds: physiology of development and germination. New York: Plenum Press, 1994. 444p.

CORTES, P.M.; SPAETH, S.C. Potassium leakage from artificially aged pea (Pisum sativum L.) embryos during imbibition. Journal of Seed Technology, v.8, p.30-42, 1994. 
DIAS, D.C.F.S.; MARCOS, FILHO, J.; CARMELLO, Q.Q.C. Potassium leakage test for the evaluation of vigour in soybean seeds. Seed Science and Technology, v.25, p.7-18, 1997.

FERGUSON, J.M. Metabolic and biochemical changes during the early stages of soybean seed deterioration. Lexington: University of Kentucky, 1988. 138p. Thesis (Ph.D.).

FESSEL, S.A. Condutividade elétrica em sementes de soja e milho em função da temperatura e período de armazenamento. Jaboticabal: UNESP/FCAV, 2001. 100p. Dissertação (Mestrado).

FESSEL, S.A.; VIEIRA, R.D.; CRUZ, M.C.P.; PAULA, R.C.; PANOBIANCO, M. Electrical conductivity testing of corn seeds as influenced by temperature and period of storage. Pesquisa Agropecuária Brasileira, v.41, p.1551-1559, 2006.

GIVELBERG, A.; HOROWITZ, M.; POLJAKOFF-MAYBER, A. Solute leakage from Solanum nigrum L. seeds exposed to high temperatures during imbibition. Journal of Experimental Botany, v.35, p.1754-1763, 1984.

HAMPTON, J.G.; TEKRONY, D.M. Handbook of vigour test methods. 3.ed. Zürich: ISTA, 1995. 117p.

LOOMIS, E.L.; SMITH, O.E. The effect of artificial aging on the concentration of $\mathrm{Ca}, \mathrm{Mg}, \mathrm{Mn}, \mathrm{K}$ and $\mathrm{Cl}$ ininbibing cabbage seed. Journal of American Society of Horticultural Science, v.105, p.647-650, 1980.

LOTT, J.N.A.; CAVDEK, V.; CARSON, J. Leakage of $\mathrm{K}, \mathrm{Mg}, \mathrm{Cl}$, $\mathrm{Ca}$ and $\mathrm{Mn}$ from imbibing seeds, grains and isolated seed parts. Seed Science Research, v.1, p.229-233, 1991.

POWELL, A.A. Seed vigour and field establishment. Advances in Research and Technology of Seeds, v.11, p.29-61, 1988.

SUN, W.Q.; LEOPOLD, A.C. The Maillard reaction and oxidative stress during aginf of soybean seeds. Physiologia Plantarum, v.94, p.94-104, 1995.
TAYLOR, A.G.; LEE, S.S.; BERESNIEWICZ, M.M.; PAINE, D.H. Amino acid leakage from aged vegetable seeds. Seed Science Technology, v.23, p.113-122, 1995.

TOMÉ JÚNIOR, J.B. Manual para interpretação de análise de solo. Guaíba: Agropecuária, 1997. 247p.

VANZOLINI, S.; NAKAGAWA, J. Lixiviação de potássio na avaliação da qualidade fisiológica de sementes de amendoim. Revista Brasileira de Sementes, v.25, p.7-12, 2003.

VIEIRA, R.D.; KRZYZANOWSKI, F.C. Teste de condutividade elétrica. In: KRZYZANOWSKI, F.C.; VIEIRA, R.D.; FRANÇA NETO, J.B. (Ed.) Vigor de sementes: conceitos e testes. Londrina: ABRATES, 1999. cap.4, p.1-26.

VIEIRA, R.D.; PAIVA-A., J.A.; PERECIN, D. Electrical conductivity and field performance of soybean seeds. Seed Technology, v.21, p.15-24, 1999a.

VIEIRA, R.D.; PAIVA-AGUERO, J.A.; PERECIN, D.; BITTENCOURT, S.R.M. Correlation of electrical conductivity and other vigor tests with field emergence of soybean seedlings. Seed Science and Technology, v.27, p.67-75, 1999b.

VIEIRA, R.D.; SCAPPA-NETO, A.; BITTENCOURT, S.R.M.; PANOBIANCO, M Electrical conductivity of the seed soaking solution and soybean seedling emergence. Scientia Agricola, v.61, p.164-168, 2004.

VIEIRA, R.D.; TEKRONY, D.M.; EGLI, D.B.; RUCKER, M. Electrical conductivity of soybean seeds after storage in several environments. Seed Science and Technology, v.29, p.599608,2001

WOODSTOCK, L.W. Seed imbibition: a critical period for successful germination. Journal of Seed Technology, v.12, p.1-15, 1988.

Received December 11, 2006

Accepted April 11, 2008 